\title{
Implementing Gagne's Events of Instruction in MBA Classroom: Reflections and Reporting
}

\author{
Dr. Suruchi Pandey
}

Associate Professor, SIMS, Symbiosis International University, Pune

\begin{abstract}
Action Research and Reflection is what defines an attribute of a professional. Class room action research is a good way of improving teaching strategies. There is no cook book approach to what will work in one subject and in another class. A teacher has to come up with his or her own style of teaching. The present study was taken the researcher who is also reporter in this case to improve on classroom experience of MBA students in HRM class. The need was identified as a reflection process and action research was conducted. The experiences of faculty are reported in the form of this paper.
\end{abstract}

Corporates are looking for trained managers and MBA degree is in demand. Students' class room experience has to impart them holistic knowledge with hands on skill. Every minute spend in class and every interaction must bring value to students. This Interaction can be with faculty or interaction among students. Faculty has to plan and conduct session smoothly. Popularly used Gagne's events of Instruction were helpful in redesigning session plan and conducting sessions. The experience was interesting and exciting. The classroom experience and learning of students was also positively improved. This paper presents brief about Gagne's Events of Instruction and is implementation in MBA HR classes. The test data of 60 students is presented for the learning. MCQ based quiz was implemented pre and post test to measure the learning.

Keywords - MBA Classes; Gagne’s Events of Instruction; Session Plan; Learning; Instruction Design

\section{Introduction}

Robert Gagne is popularly known for his contributions in the area of learning and instructional theory applied to design of instruction in several domains, such as military, flying, leadership, engineering and healthcare. Robert Gagne was a psychologist, educator, trainer, defense employee and instructional theorist. He was among the first to coin the term "instructional design" and was foremost in systematic approach to instructional design and training. A brief note on Gagne's theory is presented based on review of books on Gagne, R, Driscoll, M. (1988) "Essentials of Learning for Instruction" and Gagne, R., Briggs, L. \& Wager, W. (1992) "Principles of Instructional Design". Gagne Proposed Instruction must have nine events associated with mental conditions of learning.

Table 1. Gagne's Nine Events of instruction and Conditions of learning hierarchy

\begin{tabular}{|c|c|}
\hline Instructional Event & Conditions to learning \\
\hline $\begin{array}{l}\text { 1. Gain attention: } \\
\text { Provide stimulus to ensure } \\
\text { reception of coming instruction. }\end{array}$ & $\begin{array}{l}\text { Stimuli activates } \\
\text { receptors }\end{array}$ \\
\hline $\begin{array}{l}\text { 2. Inform learners of objectives: } \\
\text { Telling learners what they will } \\
\text { able to do following the lesson }\end{array}$ & $\begin{array}{l}\text { Creates level of } \\
\text { expectation in learning }\end{array}$ \\
\hline $\begin{array}{l}\text { 3. Stimulate recall of prior } \\
\text { learning: } \\
\text { Asking for recall of existing prior } \\
\text { knowledge }\end{array}$ & $\begin{array}{l}\text { Retrieval and activation } \\
\text { of short-term memory }\end{array}$ \\
\hline
\end{tabular}

\begin{tabular}{|l|l|}
\hline $\begin{array}{l}\text { 4. Present the stimulus: } \\
\text { Provide and Displaying the } \\
\text { content }\end{array}$ & $\begin{array}{l}\text { Selective perception of } \\
\text { content }\end{array}$ \\
\hline $\begin{array}{l}\text { 5. Provide learning guidance: } \\
\text { Supplying information relevance } \\
\text { to enhance understanding }\end{array}$ & $\begin{array}{l}\text { Semantic encoding for } \\
\text { storage long-term } \\
\text { memory }\end{array}$ \\
\hline $\begin{array}{l}\text { 6. Elicit performance: } \\
\text { Asking to respond to the } \\
\text { demonstrating learning }\end{array}$ & Retrieval, responding \\
\hline $\begin{array}{l}\text { 7. Provide feedback: } \\
\text { Providing immediate feedback on } \\
\text { learner's performance }\end{array}$ & $\begin{array}{l}\text { Reinforcement and } \\
\text { evaluation of correct } \\
\text { presentation }\end{array}$ \\
\hline $\begin{array}{l}\text { 8. Assess performance : } \\
\text { Giving feedback to learner's } \\
\text { additional performance for } \\
\text { reinforcement }\end{array}$ & $\begin{array}{l}\text { Retrieval and } \\
\text { reinforcement of content } \\
\text { as final evaluation }\end{array}$ \\
\hline $\begin{array}{l}\text { 9. Enhance retention and transfer: } \\
\text { Providing various practice to } \\
\text { generalize the capability }\end{array}$ & $\begin{array}{l}\text { Retrieval and } \\
\text { generalization of the } \\
\text { erudite skill to new } \\
\text { situation }\end{array}$ \\
\hline
\end{tabular}

The model covers minutely on each aspect of teaching and learning like domain, styles, evaluation, pedagogy etc

\section{Limitations of the Model}

Some of the limitations could be,

- It does not encourage free thinking and it is more guided.

- It may not suit subject like philosophy

- Students may not be part of active learning

- Got more popularity for system, media and e-learning.

- No mention of learning styles and pedagogy 


\section{Literature Review}

Review of various literature demonstrated successfully Implementation of Gagne's model by few teachers in school and higher education across various parts of world. There were few other examples cited in the literature using Gagne's Instruction model in various educational streams like (Catanese, 2008) on vocational education, Tsai (2008) used Gagne's model in English writing, a radiologist, Belfield (2010) also used Gagne's model in teaching chest$\mathrm{x}$-ray. Many online sources mentioned using Gagne's model in training designs as well as e learning modules. "Gagne's framework has been modified for a variety of educational settings; however, this instructional theory has not gone without controversy on the ways to implement" Commented Khadjooi, Rostami, Ishaq (2011).

Buscombe (2013) said Each of Gagne's instructional events is taken into account with specific activities for every, and with the variability of activities delineated to satisfy diverse learning styles. Gagne's instructional events can produce an efficient and comprehensive lesson plan for teaching procedural skills, preparing learners with various preferred learning styles to perform psychomotor skills competently in clinical practice. Gagne's systematic and widely referenced theory can be resourcefully and practically used. Gagne's Nine Levels of Learning offer step-by-step approach to help managers, trainers, and facilitators structure their training and therefore, their students or teams get the most from their learning opportunities mentioned in http://mindtools.com. Teaching in the large classroom setting can be challenging for faculty who seek to keep students engaged and active in the learning process highlighted Miner, Mallow, Theeke \& Barnes (2015).

Khadjooi , Rostami , Ishaq (2011) Concluded in their study Gagne's theories provide a great deal of valuable information to teachers. Applying Gagne's nine-step model is an excellent way for successful and systematic learning program as it is having structure to the lesson plans and a holistic view to the teaching. We need to stay in mind that the precise sort of these events isn't something which will be laid out in general for all lessons, but rather must be decided for every learning objective.

The 9 events of instruction could be operationalized in both synchronous and asynchronous online nursing courses opined Miner, Mallow, Theeke \& Barnes (2015). The majority of scholars possess multimodal learning styles and hence learn most effectively from a mix of activities that stimulate the visual, aural, verbal (read-write) and kinaesthetic sensory modalities. Ultimately, this lesson plan also is a model that's applicable for acquiring many other practical skills, Ng J Y (2014).
Lisak (2011) said in her blog that I was intuitively applying this instructional theory Miner, Mallow , Theeke , Barnes in their study hypothesized and concluded that use of these 9 events would facilitate student engagement and thereby enhance student learning, thus improving overall understanding of course concepts. The integration of Gagne's 9 events of instruction resulted in a positive change in student evaluations, indicating enhancement of the student learning experience. Gagne's instructional events can work in guiding the selection of suitable media in learning program, for better supporting the internal learning of the learners. Smith \& Ragan, 2000 were appreciative yet critical of Gagne's instructional model as it focuses on giving instruction but not directed for teaching.

Martin \& Klein, 2008 found the framework is flexible as the instructor can alter the order of events based on the particular learning objective to support the needed learning processes. The outcome of this instruction could also be directly observable and scientifically measured or completely hidden and assumed. To conclude, there is ample of material available about Gagne's Events of Instruction and few have used it in changing their teaching as action research. However, there is lack of study material which can provide examples of using Gagne's Model to MBA classroom, particularly theory subject. It is amazing technique of Instruction design and delivery. It focuses to increases effectiveness of learning and teaching. By adopting Gagne's technique teacher can have more engaging and retaining learning experience for students.

\section{Research Methodology}

MBA class rooms have adult learners with work experience. Sessions in MBA class rooms are blend of teaching and training. They are often large in numbers to make it more challenging for faculty. Gagne's nine events of Instructions present more structured way of conducting training sessions. MBA class rooms are for adult learner who will be soon working in corporate. By following this model in HRM lectures students learning will be enhanced and learning experiences will be relevant by correlating practice and theory.

\section{Objectives of the Study}

This action research was carried out with following objectives,

- To implement Gagne's events of Instruction in MBA HR classroom.

- To measure the impact of Gagne's event of Instruction on Students' learning. 


\section{Methods of Data Collection}

\subsection{Primary Data}

Following primary data was collected for the purpose of study,

\subsubsection{Pre and Post Test (Annexure)}

The test was prepared by the teacher based on 20 MCQ. The test was pilot tested in terms of duration, and construct of sentences. Mentor and faculty colleagues have provided their feedback on construct of the test. It was written test during the class hours and was moderated by the faculty (62 students test scores were used for analysis).

\subsubsection{Teaching Feedback (Annexure)}

Teaching feedback of faculty was collected from the students. Questionnaire was developed based on Gagne's model and students' responses were taken. This was to find out Students perspective on teaching and learning. The feedback form was circulated using google doc through email the faculty. With 10 closed ended questions and two open ended questions. 3 points scale was used to keep the feedback simple (67 students filled the feedback form).

\subsubsection{Teacher's Observation}

Teacher has maintained her observation about the classroom behaviour and change in learning of students. This was in the form of reflection during and after the class. Things that went right and things that went wrong were recorded.

\subsection{Secondary Data}

Secondary Data about the batch demographics like gender, education background and work experience were collected from admission department. Secondary data in form of literature review on the topic was conducted. The primary sources of search were internet and e libraries. The references used are mentioned in the APA format. Number of books, research papers, articles, blogs and videos were referred in the area.

\section{Data Analysis}

The data on feedback and batch background was analysed using tables, bar chart, pie chart and line graph. Marks of students were compared pre and post experiments. Ms Excel 2010 was used for statistical analysis. Paired sample two tail t-test was used to compare paired sample means to test the hypothesis. Few descriptive statistical calculations were done for the test scores of students.

\section{Scope of the Study}

The study was limited to HRM class and for 8 sessions of MBA Semester I students in Pune.

\section{Limitations of the study}

The researcher could not do too comprehensive analysis of data. Researcher used statistical techniques on advice from external expert. The researcher was cautioned about Implementation of Gagne's model may curtail student's participation. Hence some case studies and constructivist styles will be used while presenting the content and eliciting the performance stages of model. It emerged during the research that model provides flexibility of content and methodology to the faculty only sequence is restricted. Time constrains form the side of researcher along with other teaching and administrative workload.

\section{Assumptions of the Study}

- Changes in structure session will bring in change in researcher and students class room interaction in positive way.

- Students understand and filled up feedback form without bias

- Teacher is competent and has drafted objectives, methodology and evaluations

\section{Research Question}

- Will implementation of Gagne's Events of Instruction give better structure to lecture?

- Will students learning enhanced using Gagne's Events of Instruction?

\section{Scope for further study}

Study can be extended to further sessions. Student's feedback could be more rigorous in measuring impact. Gagne's events of instruction combined with few other variables could be studied.

\section{Findings and Discussion of Research}

A MCQ based test on HRM was administrated on 67 Students of a division. The test was of 20 marks and 20 questions. Total 5 students were absent either for pre-test or for post-test hence data of 62 students has been taken for further processing of scores.

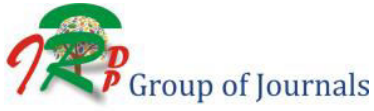




\section{Findings}

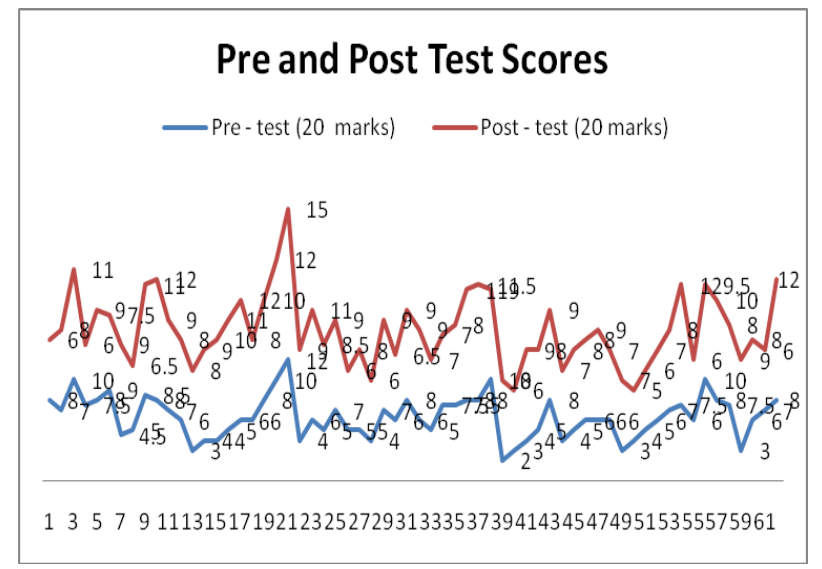

Fig. 1: Pre and post Test Scores of Students

Interpretation - The pre and post test scores plotting shows a clear difference. Most of time high scorer has scored further high. In few cases scores have gone down.

Table 2. Pre and Post Test Values

\begin{tabular}{|l|r|r|}
\hline $\begin{array}{l}\text { Statistical } \\
\text { Values }\end{array}$ & Pre Test & Post Test \\
\hline Average & 6.33 & 8.63 \\
\hline Min & 2 & 5 \\
\hline Max & 12 & 15 \\
\hline SD & 2.05 & 1.99 \\
\hline
\end{tabular}

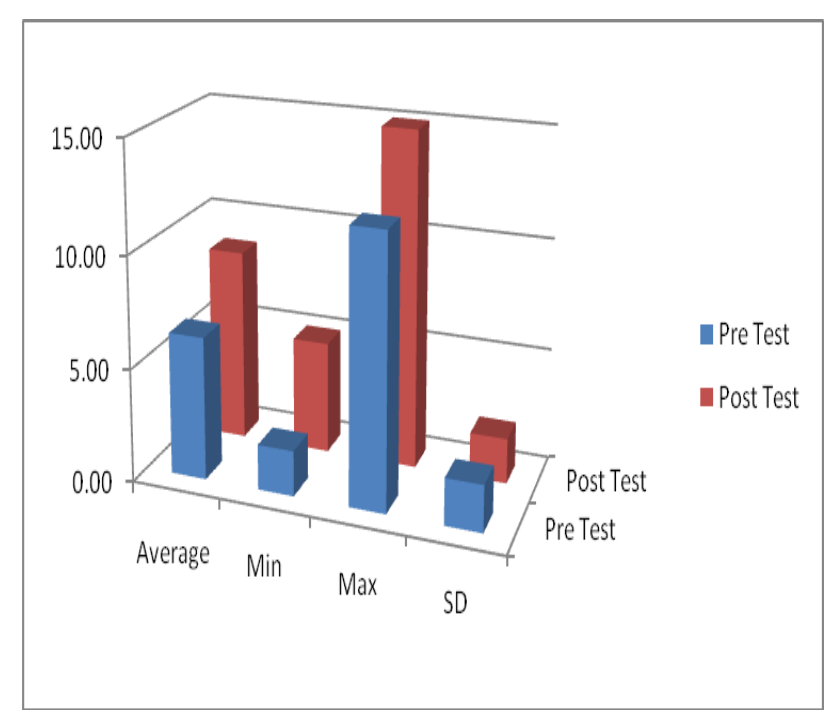

Fig. 2: Values of Pre and Post Test Scores

Interpretation - The average, min and maximum marks have gone up. Standard deviation SD has gone down post test scores.
Hypothesis Testing: The hypothesis of the study is as below,

Null Hypothesis - $H_{0}$ : there is no difference in mean between pre and post marks.

Alternate Hypothesis - $H_{1 a}$ : three is difference in mean between pre and post marks

$H_{1 b}$ : three is increase in mean between pre and post marks

Looking at the data it is evident that average scores o have changed by at least 2 marks.

Statistical Testing: Paired sample t-Test was performed on the data using excel Data Analysis formulae function.

Excel Data Analysis / $\mathrm{t}$ - test Paired sample provided following results.

Table 3. $t$-Test Results

\begin{tabular}{|l|r|r|}
\hline \multicolumn{2}{|l|}{ t-Test: Paired Two Sample for Means } \\
\hline & $\begin{array}{c}\text { Post }- \text { test } \\
(20 \text { marks })\end{array}$ & $\begin{array}{c}\text { Pre }- \text { test } \\
(20 \text { marks })\end{array}$ \\
\hline Mean & 8.63 & 6.33 \\
\hline Variance & 3.97 & 4.21 \\
\hline Observations & 62.00 & 62.00 \\
\hline Pearson Correlation & 0.50 & \\
\hline Hypothesized Mean & 0.00 & \\
Difference & 61.00 & \\
\hline Df & 8.93 & \\
\hline t Stat & 0.00 & \\
\hline P(T<=t) one-tail & 1.67 & \\
\hline t Critical one-tail & 0.00 & \\
\hline P(T<=t) two-tail & 2.00 & \\
\hline t Critical two-tail & & \\
\hline
\end{tabular}

\section{Results and Discussion}

- Paired sample two tail $\mathrm{t}$ test result -.00 i.e $\mathrm{p}<.05$ It is observed that $\mathrm{p}$ value from two tail $\mathrm{t}$-test is very low, there is very less probability that results are by chance under the null hypothesis of no difference.

The $H_{0}$ Null Hypothesis rejected ( $p<0.05$ ).

The $H_{1 a}$ Alternate Hypothesis is accepted for the purpose of study.

There is difference in the pre and post test marks.

- Paired sample one tail t-test - .00 i.e $\mathrm{p}<.05$

It is observed that $\mathrm{p}$ value from one tail $\mathrm{t}$-test is too low.

The $H_{1 b}$ Alternate Hypothesis is accepted for the purpose of study.

The post test marks have increased than pre test marks.

There is strong evidence that pedagogics improve the marks by 2 on a mean and with $95 \%$ of confidence this

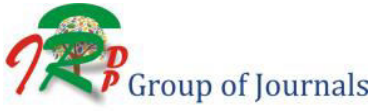


results is statistically holds true which students learning has shown improvement after the sessions.

\section{Reflections}

The study concluded that Impact of Gagne's Events of Instruction was measured and is positive and it works for large classrooms for theoretical subject.

Adopting Gagne's Events of Instruction in HR class had three major tasks:

- Changing Lesson Plan: In-depth planning of why and what I am doing

- Implementing it in class : Visualizing where things can go wrong, learning points

- Reflecting on experience : What went right and what went wrong

Planning for HRM session: It is said well began is half done. Following Gagne's events of Instruction required more planning time. Restructuring of session as per the Gagne's events of instruction was done. Preperation involved searching videos, cases, pictures, contemporary data, preparation of checklist, MCQ's, crosswords, ways to engage social media, PPT's.

Implementation in Class room: Small piece of information was discussed simple words were used and in 15 min block change in pedagogy was introduced. Some changes had to be done in last minute. Many changes like speech speed, movement in class, ask reflective questions, pre reading and post session discussion were done for the use of technology in learning and evaluation.

Observations about conduct in Class: Keeping record of the sessions and observation really helps a faculty. Each year new student and different calibre, Interesting questions posed and discussions flows. Engaging in reflection and action research is a desired competency of a teaching profession. "Smooth sea doesn't make skilful sailor" Classroom challenges have to be there to train teacher deal with them better.

\section{Conclusion}

Applying Gagne's nine-step model is an excellent method to ensure an effectual and systematic learning program as it provides structure for the lesson plans and holistic approach to the teaching. A lesson design may be a plan showing the sort of instructional events, their order and therefore the quite activity happening in each event. In designing a lesson plan, there are two important factors: the objectives and therefore the learners. Becoming an honest teacher, one who meets the requirements of all learners, isn't a simple task. However, I even have learned that the primary step therein process is consciousness of this challenge. However, I have learned that the first step in that process is consciousness of this challenge.

Gagne's nine instructional events were a proper and sound pedagogy to use in MBA class although over the years Gagne's instructional model has proven to be effective in different learning and training aspects, this study again proves that Gagne's model provides a proper and sound pedagogy to use in MBA HRM classes. Besides, it also shows this model can flexibly accommodate the use of multiple pedagogical elements in presenting the information. Student's retention and learning outcomes were improved. Learning is to learn about teaching on continuous basis. Brookfield (2015) said "We assume good Teacher is like a skillfull archer with a quiver full of powerful arrows. Whenever problem arises we should be able to reach into our quiver, choose the appropriate arrow, fit it to our bowstring and hit the heart of the problem, thereby resolving it." Teacher is like an archer. A skillfull archer ought first to know the mark he aims at, and then apply his hand, his bow, his string, his arrow and his motion accordingly to target, to this extent teacher must know the identify learning problems in class and deal with it by right pedagogy and correct tools. One pedagogy or teaching style will not meet all learners requirement and hence conjunction of learning style and pedagogy must be there.

Businessmen said "Cash is the King" In academics "Content is the KING"!!!

They check on the cash flow as a teacher we have to check on the content flow.

\section{References}

[1] Buscombe, C, (2013). Using Gagne's Theory to teach procedural skills. The Clinical Teacher, 10:302-307(Doi: 10.1111/Tct.12051), database. https://www.Ncbi.Nlm.Nih.Gov/Pubmed/24015735.

[2] Bednar, A.K, Cunningham, D. Duffy, T. M \& Perry, J. D, (1991). Theory into Practice: How do we Link? In G. Anglin (Ed.), Instructional Technology: Past, Present and Future, 88-101, Retrieved from Englewood, Co: Libraries Unlimited.

[3] Brown, J. S, Collins. A \& Duguid. P,(1989). Situated Cognition and the Culture of Learning. Retrieved from Educational Researcher, $18(4), 32-42$.

[4] Catanese, A.P. (2008). Gagne's Nine Events of Instruction. Conditions of Learning Theory 1-3. Northern Illinois University, Faculty Development and Instructional Design Center The University of West http://www.niu.edu/facdev/_pdf/guide/learning/gagnes_nine_events instruction.pdf

[5] Gunter, G. A, Kenny, R.F, Vick, E.H. A Case for A Formal design paradigm for serious Games. Retrieved from Formal Design Paradigm-2.

[6] Khadjooi, K, Rostami, K \&Ishaq, S, (2011). How to use Gagne's Model of Instructional design in teaching psychomotor skills: Gastroenterol Hepatol Bed Bench, 4(3) database: https://www.Ncbi.Nlm.Nih.Gov/Pmc/Articles/Pmc4017416/ 
[7] Kevin, K, (2008). Gagne's Nine Events of Instruction: An Introduction, Database: http://www.E-Learningguru. Com/Articles/ Art3_3.htm

[8] Leow, F T \& Neo, M (2014). Interactive Multimedia Learning: Innovating Classroom Education in a Malaysian University: The Turkish Online Journal of Educational Technology Tojet, 13(2), 99110

[9] Lisak, M, (2011). Educational Technology \& Pedagogy: Gagne's Nine Events of Instruction, database: http://Koreamaria. Typepad.Com/Gwangju/2011/08/Gagnes-Nine-Events-OfInstruction.html

[10] Mettetal, G (2012). The What, Why and How of Classroom Action Research. Journal of The Scholarship of Teaching and Learning, 2(1), 6- 18

[11] Miner, A. Mallow,J.Theeke,\&L.Barnes,(2015). Using Gagne's 9 Events ofInstruction to Enhance Student Performance and Course Evaluations in Undergraduate Nursing Course,Nurse Educ. 40(3): 152-154, Doi: 10.1097/Nne.0000000000000138

[12] Manninen. E. Use This Tool to Structure and Deliver Training Effectively Gagne's Nine Levels of Learning Training Your Team Effectively, Retrieved from Article Mind Tools.com

[13] Martin. F \& Klein. J, (2008). Effects of Objectives, Practice, and Review in Multimedia Instruction .Journal of Educational Multimedia and Hypermedia 17(2), 171-189.

[14] Ng \& J.Y, (2014). Combining Peyton's Four-Step Approach and Gagne's Instructional Model in Teaching Slit-Lamp Examination : Perspect Med Educ, 3(6): 480-485,Doi:10.1007/S40037-014-0136$\mathrm{X}$.

[15] Pickard. M, (2007). The New Bloom's Taxonomy: An Overview for Family and Consumer Sciences. Journal of Family and Consumer Sciences Education, 25(1), 45- 55.

[16] Preparing and Structuring Lecture Notes, Database http://Cet.Usc.Edu/Resources/Teaching_Learning/Docs/Teaching_N uggets_Docs/3.1_Preparing_And_Structuring_Lecture_Notes.Pdf accessed on June 2016.

[17] Toward Meeting the Needs of all Learners: An Action Research Report Prof 191V, (2000), Queen's University, Anonymous Teacher

[18] Tsai, C.J. (2008). Application of the Events of Instruction in the Gagné-Briggs ISD Model: A Design Example in Language Instruction. Available: http://www.academia.edu/4381265 /Application_of_the_Events_of_Instruction_in_the_Gagn\%C3\%A9Briggs_ISD_Model_A_Design_Example_in_Language_Instruction
[19] Yasmeen, G,(2008). Action Research: An Approach for the Teachers in Higher Education. The Turkish Online Journal of Educational Technology - Tojet, 7 (4) Issn: 1303-6521,46-53.

[20] Wildman, T. M. (1981). Cognitive Theory and the Design of Instruction. Retrieved from Educational Technology, 21, 14-20.

[21] Winn, W. (2004). Cognitive Perspectives in Psychology, 79-112. Retrieved from Handbook of Research On Educational Communications and Technology.

[22] BCIT. (2003). Preparing Lesson Plan. BCIT Learning and Teaching Centre. Retrieved from: http://www.bcit.ca/files/idc/pdf/htlessonplans.pdf, July 9, 2010.

[23] Blanchard, Thacker\& Ram, (2010). Effective Training: Systems, Strategies and Practices. Pearson Publication (pp 200-205).

[24] Gagne. R \& Driscoll. M, (1988). Essentials of Learning for Instruction. Retrieved from Englewood Cliff.

[25] Gagne. R., Briggs. L. \& Wager, W, (1992). Principles of Instructional Design (185-257). Retrieved from Fort Worth, Tx: Hbj College Publishers. database :https://www.Hcs64.Com/Files /Principles\%20of\%20instructional\%20design.Pdf

[26] Rao, V.S.P,(2001). Human Resources Management: Text and Cases, Excel Books.

[27] Ragan, T.J, Smith, P.L. (2000) Conditions Theory and Models For Designing Instruction database : http://www.aect.org/edtech/24.pdf.

[28] Stephen D. Brookfield (2015) The Skillful Teacher: On Technique, Trust, and Responsiveness in the Classroom. Retrieved from Wiley Publications.

[29] J. Marques, S. Dhiman, J. Biberman (2011).Stories to Tell Your Students: Transforming toward Organizational Growth, Springer Publication, Springer Publicatons https://Resources.Instructure.Com/ Courses/ 7/Pages/Robert-Gagne

[30] https://Coursearc.Com/Gagnes-Nine-Events-Of-Instruction/

[31] http://Edci672.Wikispaces.Com/Gagne's+Nine+Events+Of+Instructi ( Jan 2016)

[32] http://citt.ufl.edu/tools/gagnes-9-events-of-instruction/ ( Jan 2016)

[33] http://my-ecoach.com/project.php?id=12152\&project_step=28465 (Jan 2016)

[34] http://learnenglish.britishcouncil.org/en/node/9193/

[35] http://cte.rice.edu/blogarchive/2015/09/13/isteachingartorscience

[36] http://toddphilipp.weebly.com/is-teaching-an-art-or-a-science.html

[37] Robert Mills Gagne (2013). Portrait of a Theorist database : https://www.youtube.com/watch?v=FgDcUnObLqI 